OPEN ACCESS

\title{
Challenges in Integrity of Sport: Current Practices and Preventive Approaches of Sport Corruption in Sri Lanka
}

Authors' contribution:

A) conception and design of the study

B) acquisition of data

C) analysis and interpretation of data

D) manuscript preparation

E) obtaining funding

\author{
A. A. L. Madhushani
}

Sabaragamuwa University of Sri Lanka, Sri Lanka

In many countries, including Sri Lanka, control of sports is connected to political power of the state and therefore, the political patronage decisively influences sports, both in and out of the playground. This study looks at few identified areas relating to the impact of mal-governance and corruption in sports administration, and how general governance structure adversely affects sports integrity in Sri Lanka. The content analysis was performed on articles pertaining to the sport corruption in Sri Lanka. The analysis has shown that the sport corruption is a main and considerable issue in Sri Lanka due to the several reasons. The study recommended that the proper governance policy should be invented to the sport sector to prevent this issue.

KEYWORDS mal governance, integrity, sport corruption, governance policy

\section{Sports governance and structural politicization of sports administration}

Sports allow billions of individuals to experience emotions and learn values such as following a set of commonly accepted rules and respect for others. Sports by its very nature maintain stimulation, harmony and passion. Sport is also a multibillion dollar business with intricate ties with political and private interests. It is now recognized that sports have great potential for corruption due to its exploitation by vested interest for personal gain, huge investment opportunities, opportunities to exploit emotions, and influence of sports in politics and business.

High profile cases of corruption, doping, and match fixing in sport, as well as mismanagement and lack of efficiency within sport governing bodies (SGB) have resulted since the beginning of the 21st century. According to the Henry \& Lee (2004), the concept grew rapidly in different parts of the world, tinted with different cultures, framed with different theoretical influences (such as corporate governance or democratic governance), and with a variety of different titles such as "best practices", "principles of conduct" or simply "governance". "The NOCs must preserve their autonomy and resist all pressures of any kind, including but not limited to political, legal, religious or economic pressures, which may prevent them from complying with the Olympic Charter' (article 28.6).

Deviating from the self-regulation of sports by sports associations and clubs, in 1973, the Sports Law was introduced, in line with the policies of the then government. The Law introduced for the establishments of a National Sports Council, sports committees and national sports associations. The salient feature of the Law is 
the unbridled powers vested in the Minister, to directly interfere with the national sports at every level. Summary of such permissible interferences include the following:

a) the National Sports Council consists of appointees of the Minister. Those members are removable by the Minister without reasons (sections 4 \& 7),

b) the Minister may establish district sports committees, and the members of those committees are also removable by the Minister without reasons (sections $11 \& 14$ ),

c) National Associations of each sport are required to be registered, with the Ministry of Sports, and the decision to recognize such association, is left to the Minister(sections $28 \& 29$ ). The Minister also has appellate powers, on his own, against his own decision. (section 30). It is the Minister who prescribed regulations on the recognition of associations. (section 31). It is the Minister, who refuses registration, suspends or cancels the registration, or dissolves a national association of sports (sections $32 \& 34$ ),

d) the sports associations are elected. However, section 33 of the Sports Law read with the Regulations made under the Sports Law, permits the Minister, to make "interim arrangements after suspending an association",

e) the Minister also controls the participation in sports in Sri Lanka or abroad of any individual participants or teams, representing Sri Lanka.

In Sri Lanka, we have also witnessed, during the last decade of continuous suspensions of associations, and Ministers appointing Interim Committees to run sports governing bodies. The situation has been aggravated with politicians, active or retired, becoming heads of national associations of sports. An interesting development is the inexplicable increase of serving and retired military officials being involved in sports administration, bringing in a different dimension affecting overall civil sports governance structure. It is in that background that sports governance can be truly understood in Sri Lanka.

Sports governance related challenges were often limited to closed door isolated discussions but occasionally, in the recent time, the importance of sports autonomy and need to be independent of political interference was raised in the context of National Olympic Committee (NOC). It is pertinent to note that 25 sports Federations/Associations are affiliated to the NOC5 and many of those associates are run by interim administrations appointed by the Minister. The tussle between the Sports Ministry and the NOC into the question of autonomy of the sports recently ended up with certain agreements reached between the International Olympic Federation and Ministry of Sports, which can be summarized as follows:

- The sports law (in force since 1973) will be revised within nine months, and the specific government regulations derived from the sports law will be reviewed within six months in order to make them compatible with the basic principles which govern the Olympic Movement. To that effect, and to ensure proper consultation with all concerned parties, a working group will be established immediately between the Sports Ministry and the NOC/ national sports federations, also involving the IOC (representing the Olympic Movement as a whole)

- All national sports federations will have to liaise with their respective Federations to review their constitutions/ statutes in accordance with the International Federations standards and the principles of the Olympic Movement. This process must be completed within six months under the supervision of each International Federation concerned, which will also decide, on a case-by case basis once this process is completed, whether new elections will be required in the respective national federations.

- The NOC Constitution will also be reviewed with the IOC in order to ensure full compliance with the Olympic Charter and the IOC s requirements. Then, the revised draft Constitution will have to be submitted to the NOC General Assembly for adoption, and be approved formally by the IOC. The new NOC Constitution will serve as a basis to conduct the NOC elections. This process (including the revision of the NOC Constitution and the NOC elections) will also be completed within six months. Until the NOC elections take place, the current NOC s office-bearers will remain in place. 
Despite the aforesaid agreements and a working paper being submitted by the NOC on how to make sports legal regime compatible with international practices and Olympic Charter removing intrusive provisions, there is no evidence of any commitment on the part of the Sports Officials to implement the agreement. Unless these agreements are fulfilled, there is likelihood of Sri Lanka being suspended from the Olympic movement as happened in India in 2012.

With the present system of Constitutional governance where power is concentrated in the hands of the President while the public service is strappingly politicized, the sports administration may not find the required level of autonomy. However, as appears from the above, the national sports administrations are required to follow international standards in relation to sports as well as sports administration. It is pertinent however to remind ourselves of the Olympic Charter and the Fundamental Principles of Olympism, initially contained a philosophy but have now become virtually binding instruments on sports authorities. Given below are three of the seven Fundamental Principles, which may be relevant for the purpose of this Chapter:

1. The practice of sport is a human right. Every individual must have the possibility of practicing sport, without discrimination of any kind and in the Olympic spirit, which requires mutual understanding with a spirit of friendship, solidarity and fair play.

2. Recognizing that sport occurs within the framework of society, sports organizations within the Olympic Movement shall have the rights and obligations of autonomy, which include freely establishing and controlling the rules of sport, determining the structure and governance of their organisations, enjoying the right of elections free from any outside influence and the responsibility for ensuring that principles of good governance be applied.

3. Any form of discrimination with regard to a country or a person on grounds of race, religion, politics, gender or otherwise is incompatible with belonging to the Olympic Movement."

All international sports bodies such as International Olympic Committee, International Cricket Council and Federation of International Football Association (collectively called for the purpose of this chapter as International Councils) are nongovernmental organizations established to promote and regulate specific sports; and all national sports associations are members and stakeholders of those International Councils which standardize the international sports. Through the respective Charters and founding documents and decisions, all national sports bodies are bound to honor the fundamental values and decisions of those International Councils. In view of these international sporting obligations, and to be part of international sporting Councils, it is necessary for the Sri Lankan authorities to ensure sports autonomy, freedom from political discrimination and good governance standards in all types of sports administrations.

\section{National sports policy and practice}

The Sports Ministry, in its website sets out the overview and the functions of the Ministry of Sports. It discloses the objectives of the Ministry, which are as follows:

- to make Sport and integral part of Sri Lankan Culture and Society,

- to utilize Sports to improve health and physical wellbeing and enhancing the living conditions of all Sri Lanka,

- to provide knowledge, space and opportunities to everyone to participate in sports,

- to provide resources and infrastructure facilities required to develop sports as a whole,

- to assist every Sri Lankan to rise to the highest level in sports and converting Sri Lanka to substantial status reflecting clearly the image gained by it internationally as a successful nation endowed with skills in sports,

- to improve the sports industry in Sri Lanka and develop the economy by providing new job opportunities, 
- to use sports as a major foreign exchange earning field in Sri Lanka.

In addition, on 16 May 2012, the Minister of Sports have published 11 paged Gazette notifications detailing the National Sports Policy of Sri Lanka, highlighting, among others, the policy to create the environment necessary to ensure the independence of sports organizations.

Unfortunately, there is no independent evaluation available in public domain to assess whether the Sports Ministry has achieved its objectives. There is no independent verification whether the sports authorities in Sri Lanka has followed National Sports Policy, particularly to ensure independence of sports organizations. Having regard to the structural politicization, one can conclude that the practice seems to be contrary to these disclosed policies. It is significant however, that there are no disclosed criteria in many vital aspects of sports such as recognizing a new sport as a national sport, allocation of resources (including for infrastructure), selection criteria of players, how sports economy is managed. Unfortunately there is no evidence in the public domain to promote good governance and transparency in sports organizations or in the Ministry, though the National Sports Policy emphasizes the need to ensure accountability through good governance and transparency.

\section{Broadcasting /telecasting rights of sports}

Sports such as cricket, has competitive international value for TV sponsorships. The Carlton Sports Network (CSN), secured from Sri Lanka Cricket (SLC), the TV rights for 3 years, for a sum of Rs 125 million in 2012. CSN has commenced its operations only on 7th March 2011. An investigative article published in a leading Sunday newspaper, traced the profile of CSN, connecting to the ruling party and its political hierarchy of the government. There is no doubt that CSN had received TV sponsorship without any proper evaluation by Sri Lanka Cricket. To make things worse, the Secretary of SLC is the Chief Executive Officer of CSN There is an obvious conflict of interest of the CEO of CSN. Had there been any bids or bid evaluations on the performance of bidders and financial viability, and evaluation of past audited accounts of the bidders, CSN could not have secured TV sponsorship. There is also inexplicable silence, on the part of the State owned television stations (Rupavahini and ITN), or the private TV stations such as MTV, why they have not submitted bids for TV sponsorship. It was later revealed that there was no wide publicity given for the calling of bids. Those TV stations have previously secured the bids in competitive market.

Investigations into the TV rights of CSN also discloses interestingly, how Sri Lanka's TRC grants TV operation license and how sports related corruption is linked to wider governance issues in the country. Telecommunication Regulatory Commission - TRC (established under Act No 25 of 1991 amended by 27 of 1997) is headed by the Secretary to the Ministry. Presently the Ministry of Media is a portfolio held by the President. The Director General of TRC, who is a paid employee, is also a member of the Board. There are series of allegations of TRC of having being involved in direct political activities, such as sending free SMS messages from a presidential candidate (The President, who is also the Minister) during election campaigns. After President Rajapaksha assumed office on 19th November 2005, 12new TV channel licenses were given, amongst them CSN. However, CSN commenced operations only on $7^{\text {th }}$ March 2011. This shows how the political authorities have had a hand in firstly securing a TV broadcasting license, and then, in securing financial gold mine of cricket broadcasting license for a meager amount.

\section{Infrastructural developments and Corruption}

Sports are closely linked to infrastructural development, particularly when such sport is a national game involving a large population. In Sri Lanka we have seen many such infrastructural developments in the game of Cricket. Sri Lanka presently has 11 cricket stadiums. In 2009, two new stadiums were built in Thanamalwila (Mahinda Rajapaksa International Cricket Stadium) and Pallekelle, with a capacity of 35000 spectators 13 in each stadium, in preparation of the 2011 World Cup. There is no evidence of 
Feasibility study or need assessment of such new stadium for Sri Lanka, in addition to the existing 10 stadiums. It was reported in 2013 October that the Sri Lanka Cricket is negotiating with the Government to have Rs.3.2 Billion debt incurred for the building of stadiums written off. In 2011, COPE questioned the former interim committee members of Sri Lanka Cricket, after the Auditor General's Department's report on Sri Lanka Cricket. According to the media, the Report revealed a Rs. 290 million overdraft, and expenditure of Rs.4 billion in excess of the amount allocated for preparing three play grounds for the cricket world cup and negligence on the part of the administration. Though new stadiums were built, the Sri Lanka Cricket has no funds or capacity to manage these stadiums. Military, which is occupying the building, is maintaining these infrastructures, again at the public cost. Sri Lanka cricket has a massive cadre over 280. These details disclose the internal management failures and how overall political commands dictate to the sports governance. One famous sports commentator, Vaibhav Vats, comments on this cricket stadium as follows 18. "After a monotonous hour long drive, the cricket stadium appeared. Two floodlights towers rose above the surrounding jungle. MAHINDA RAJAPAKSA INTERNATIONAL CRICKET STADIUM - the name was inscribed in baroque capital lettering. There was little hum an activity in its vicinity. I could not think of a stranger location for a cricket stadium."

As pointed out above, Official website and the sports policy announced that sports would be an active contributor to the economic development of the country, and therefore one would expect the Sports Ministry in sports governance to bear in mind the value for money in huge investments made in the name of sports. However, the unanswered questions of these new stadiums, economic losses and secrecy of decision making reveal the context in which games are exploited for personal gain, through infrastructure development opportunities.

\section{Recommendations}

Politicization of sports associations has created multiple challenges to sports integrity, particularly the autonomy of sport and social acceptance of the sports. Politicization of sport has made sports associations extremely vulnerable for all forms of corruption such as conflict of interest, misappropriation, fraud, manipulations etc., with the risk of taking the game away from the sports loving citizens. Thus it is critical that the Sports Law is amended taking away the Minister's intrusive interferences into sports associations. Such amendments should ensure that sports associations are accountable to public and to the stake holders, while protecting the game against vested interests.

Sri Lankan sports require a review of its internal governance. It should also ensure Transparency and accountability in its decision making process and operations. In addition to auditing of their accounts, the associations should be more open on use of their funds and policies. This should commence initially with major sports such as cricket, volley ball, football, rugby and athletics. However, this will not be sufficient unless the Ministry of Sports encourages international governance within its own Ministry as well. All those who are involved in sports should understand the governance structures, policies, procedures and the finances of the sports associations. This would be futile unless detailed financial reporting of funds is not made. The sports associations must be open to outside scrutiny. Their attitude of an "old boys' network", 'our click' will vitiate such standards. Sports associations should have a public policy of zero tolerance of corruption in all vulnerable stages such as selection of players, contracting, infrastructure development, TV broadcasting, ticket sales etc., All sports associations should encourage independent whistle blower protection policies. Whistle blower procedures should be confidential and accessible to all the stake holders of the game. In Sports involving agents and intermediaries such as cricket, there should be clear guidelines for due diligence checks on all members of syndicates or franchises. Private promoters should be subjected to strong scrutiny. Each sport association should have an anti-corruption policy and an anti-corruption unit, consistent with global practices.

National sport administrations are part of international sports bodies, which operate under founding documents and Charters containing certain international standards and values. It is incumbent upon national authorities to 
operate the games in keeping with those international standards. Therefore, it is necessary to change the existing laws and practices in keeping with international standards and the implement it candidly. Importance of introducing National Policies and National Rules Governing Sports will be negated by not implementing core values of those policies.

\title{
REFERENCES
}

Chappelet, J.L. \& Mrkonjic, M. (2013). Basic Indicators for Better Governance in International Sport (BIGIS). An Assessment Tool for International Sport Governing Bodies. IDHEAP Working Paper, Lausanne: Swiss Graduate School of Public Administration.

Carlton sports network and Somerset-entertainment. Retrieved from www.thesundayleader.lk/2011/07/24/ Weliamuna on Surrendering Air wavaves and Liberty to Napotism http://groundviews. org/ 2012/ 06/ 11/ surrender ingairwaves-libertyto-nepotism

Daily mirror news. Retrieved from http://www.colombopage.com/archive_11B/Nov 03 / 1320327252KA.php

Democratic Socialist Republic of Sri Lanka Gazette, Part II, November 15, 2013. printed at the department of government printing, Sri Lanka

Gazette Extraordinary 193/3 15th January 2013 Gazette, printed at the department of government printing, Sri Lanka.

Henry, I. \& Lee, P.C. (2004). Governance and ethics in sport. In S. Chadwick \& J. Beech (Eds.), The business of sport management (pp. 25-42). Harlow: Pearson Education,.

Horne, J. (2016). The planning and hosting of sports mega-events: Sources, forms and the prevention of corruption. In G. Sweeney \& K. McCarthy (Eds.), Global Corruption Report (pp. 163-168). NY: Routledge.

International Olympic Committee. (2016). Olympic Charter: In force as from 2 August 2016. News detail by IOC summons-sports-minister. PRetrieved from http://www.ceylontoday.lk/34-47776-news-detail-ioc-summons-sportsminister.

Notification No.1758/23 dated 16 May 2012 Gazette - item 16, printed at the department of government printing, Sri Lanka.

\section{AUTHOR'S ADDRESS:}

\author{
A. A. L. Madhushani \\ Department of Sports Sciences and Physical Education \\ Faculty of Applied Sciences \\ Sabaragamuwa University of Sri Lanka \\ P.O. Box 02, Belihuloya \\ Sri Lanka \\ E-mail: lakshika@appsc.sab.ac.lk
}

Received: 12 October 2018; Accepted: 24 May 2019 